
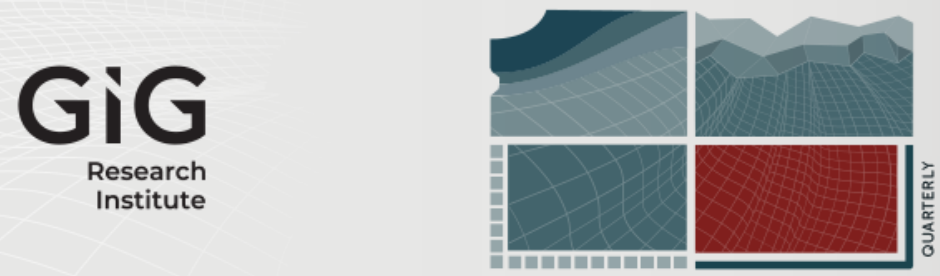

JOURNAL

OF

SUSTAINABLE

MINING

\title{
Optimization of the Distribution of Drilling Boreholes in Methane Production from Coal Seams
}

Author(s) ORCID Identifier:

Anna Wątor (iD 0000-0003-4243-0853

Jarosław Chećko (iD) 0000-0001-7926-1702

Tomasz Urych (iD 0000-0003-1827-028X

Follow this and additional works at: https://jsm.gig.eu/journal-of-sustainable-mining

Part of the Geology Commons, and the Mining Engineering Commons

\section{Recommended Citation}

Wątor, Anna; Chećko, Jarosław; and Urych, Tomasz (2020) "Optimization of the Distribution of Drilling Boreholes in Methane Production from Coal Seams," Journal of Sustainable Mining: Vol. 19 : Iss. 4 , Article 6.

Available at: https://doi.org/10.46873/2300-3960.1024

This Research Article is brought to you for free and open access by Journal of Sustainable Mining. It has been accepted for inclusion in Journal of Sustainable Mining by an authorized editor of Journal of Sustainable Mining. 


\title{
Optimization of the Distribution of Drilling Boreholes in Methane Production from Coal Seams
}

\begin{abstract}
The paper presents an evaluation of methane production from coal seams. The Warszowice-

PawłowicePółnoc deposit was selected for numerical modelling of methane production. The numerical

model was made for a fragment of this deposit of about $2 \mathrm{~km}^{2}$. The numerical model was constructed for 6 seams. Three deposits were selected for simulation of methane production. Three horizontal boreholes were designed within the model area, referring to the existing Suszec-19 borehole. A number of simulations related to methane production from the selected deposits were performed. They included different variants of the number of boreholes and also took into account the z-pinnate method. The analyses proved that the most advantageous is the production of 3 directional boreholes simultaneously with the z-pinnate method. For this variant the degree of methane production was $21.9 \%$ of the estimated resources.
\end{abstract}

\section{Keywords}

CBM, coal bed methane, numerical simulations, methane production

\section{Creative Commons License}

\section{(c) (i)}

This work is licensed under a Creative Commons Attribution 4.0 License. 


\title{
Optimization of the distribution of drilling boreholes in methane production from coal seams
}

\author{
Anna Wątor*, Jarosław Chećko, Tomasz Urych
}

Central Mining Institute, Plac Gwarków 1, 40-166, Katowice, Poland

\begin{abstract}
The paper presents an evaluation of methane production from coal seams. The Warszowice-Pawłowice Północ deposit was selected for numerical modelling of methane production. The numerical model was made for a fragment of this deposit of about $2 \mathrm{~km}^{2}$. The numerical model was constructed for 6 seams. Three deposits were selected for simulation of methane production. Three horizontal boreholes were designed within the model area, referring to the existing Suszec19 borehole. A number of simulations related to methane production from the selected deposits were performed. They included different variants of the number of boreholes and also took into account the z-pinnate method. The analyses proved that the most advantageous is the production of 3 directional boreholes simultaneously with the $z$-pinnate method. For this variant the degree of methane production was $21.9 \%$ of the estimated resources.
\end{abstract}

Keywords: CBM, coal bed methane, numerical simulations, methane production

\section{Introduction}

$\mathrm{T}$ he global development of the economy requires an increase in electricity consumption, which leads to a continuous increase in demand for electricity. In Poland, the primary source of energy is mainly hard coal and lignite. The use of these fuels causes large environmental pollution, which also has an impact on global climate warming. The economy of the whole world tries to replace fossil sources with other fuels such as methane. In Poland, methane occurs mainly in gas deposits (conventional) and in coal seams (unconventional) in hard coal deposits (CBM - coal bed methane) [1]. Although methane combustion is a source of $\mathrm{CO}_{2}$, its emission to the atmosphere is much lower than that of coal [2]. The problem of methane presence in coal beds has been dealt with for many years [3-6], including laboratory tests related to this issue [7-9]. It has inherently been a threat occurring during exploitation of coal seams. This gas was discharged from the mine workings to the surface through a ventilation system. From the beginning of the 70s of the last century, interest in methane as an energy raw material began.

The presence of methane in coal is related to the process of coal formation. It is believed that in coal with a low degree of carbonization, methane is formed as a result of micro organism's presence, while in coal with a higher degree of carbonization as a result of thermal processes of organic matter [2].

Organic matter accumulated in the marshes as a remnant of lush vegetation, growing on Earth during periods when the climate was hot and the pressure and organic matter was compressed. As a result, chemical and physical reactions began to take place, leading to the formation of coal, methane, carbon dioxide, nitrogen and water. As the organic matter deposits deepened, pressure and temperature increased, leading to an increasing degree of coalification of the material and an increase in methane content.

Sorbed methane and free methane are in the rock mass in mutual equilibrium, determined by gas pressure. An increase in pressure causes the absorption of methane in the coal seam, while a decrease in pressure

Received 16 October 2020; revised 24 November 2020; accepted 6 December 2020.

Available online 22 December 2020

* Corresponding author.

E-mail addresses: awator@gig.eu (A. Wątor), jchecko@gig.eu (J. Chećko), turych@gig.eu (T. Urych). 
is caused by e.g. geological processes and mining activities - its desorption and migration into surrounding rocks or into the atmosphere. The amount of free methane in the waste reservoir rocks depends on their volume, porosity, gas saturation and deposit pressure. The amount of methane adsorbed on coal, on the other hand, depends on many factors, the most important of which are the sorption properties of coal, temperature and deposit pressure. The increase in coalification and pressure, with a decrease in coal humidity and temperature, are conducive to methane accumulation in the deposit [2].

The specificity of coal structure, as a rock medium, is that the amount of methane in coal is higher than the amount of gas that could be contained in a traditional deposit of the same porosity as coal. In the theory of sorption processes, there are many models which allow the description of this process. The most commonly used model describing the phenomenon of sorption of gases and liquids on the surface of solids is the Langmuir adsorption model. The amount of absorbed methane in coal according to model based of the Langmuir adsorption can be explained by equation (1) $[2,10]$ :

$\frac{\mathrm{p}}{\mathrm{a}}=\frac{1}{K \mathrm{a}_{\mathrm{m}}}+\frac{\mathrm{p}}{\mathrm{a}_{\mathrm{m}}}$

where:

$p$ - equilibrium pressure,

$a$ - the amount of absorbed methane per unit mass of coal,

$m$ - the amount of absorbed methane assuming a unimolecular layer,

$K-$ a balance constant of adsorption, determined experimentally.

The amount of absorbed methane depends on many factors, such as:

- humidity,

- content of light fractions,

- carbon content,

- ash content,

- temperature.

The recovery of methane from coal seams is characterized by a degassing factor $R_{f}$, defined by relation $(2)[2,10]$ :

$R_{f}=\frac{C_{g i}-C_{g a}}{C_{g i}}$

where:

$C_{g i}$ - initial amount of absorbed methane,
$C_{g a}$ - the amount of methane remaining in the coal after the exploitation process. In industrial practice, the aim is to make the degassing factor as high as possible. For this purpose, appropriate methane extraction technologies must be used.

Methane accumulated in hard coal deposits can be obtained in three ways:

- during the current operation of the mines through a degassing drilling system, conducted from the mine workings in order to remove methane. In this case, the methane is discharged with ventilation air or discharged with methane drainage systems with the possibility of energy use. A gas with a methane concentration from 60 to $95 \%$ is obtained,

- from drilled boreholes to coal mines, where mining has been ceased (drilling to mining gobs). Gas with methane concentration from 20 to $70 \%$ is obtained,

- from drilled boreholes for intact hard coal seams are the drilling of vertical, directional or horizontal holes from the surface. The gas is obtained with methane concentration of about $90 \%$ [2].

In China, vertical and directional boreholes are currently used, and horizontal boreholes in various configurations. Horizontal boreholes can be in letter, L, U, V and multi-bottom horizontal boreholes such as fishbone shaped/pinnate, tree-like shapes [11].

U-shaped boreholes are more efficient than the others and it is possible to regenerate them in case of clogging by coal particles, which extends the life cycle of CBM boreholes. However, the cost of drilling such a borehole is much higher than L- or V-shaped boreholes. Before drilling such a hole, an economic analysis should be made, taking into account such elements as cost, efficiency and life cycle of the borehole [12].

3D geological modeling of hydrocarbon resources plays an important role in the processes of prospecting, exploring, developing and exploiting hydrocarbon accumulations. Schlumberger Petrel is an example of software which enables to perform numerical simulations of Coal Bed Methane extraction by means of directional drilling from the surface [13-15], as well as computer simulations of enhanced methane recovery combined with injecting $\mathrm{CO}_{2}$ into the coal seams - Enhanced Coalbed Methane (ECBM) [16-20].

The purposed of this article is to present the results of numerical simulations aimed at optimizing the methane drainage process by selecting appropriate system of boreholes using the ECLIPSE reservoir simulator [21]. As part of the research, simulations of methane production were performed 
using numerical model of real hard coal deposit developed using the Petrel software [22].

The aim of these tests was to compare the production of methane for the assumed six variants including gas intake from one, two and three seams for assumed two types of boreholes: (1) directional wells and (2) system of horizontal boreholes in a multi-well pattern using zpinnate method with lengths of $200 \mathrm{~m}$, drilled at an angle of $45^{\circ}$.

The results of the research carried out will allow for the selection of the most advantageous system of boreholes for the extraction of methane from coal seams and it can help in the analysis of the possibility of using the selected system of boreholes for the extraction of methane from the entire deposit.

\section{Materials and methods}

The methane production processes from coal deposits have been estimated on the basis of an ECLIPSE simulator with Coal Bed Methane option, which has defined mechanisms responsible for the flow of gases and water in the coal beds (desorption of gas from the coal matrix into the fracture system, diffusion into the matrix according to Fick's law and Darcy's flow in the fractures). The ECLIPSE 300 option was used in the modelling, which takes into account the double porosity, which combines a coal matrix and fracture system. Methane is stored through sorption in a very poorly permeable coal matrix with a different porosity in relation to the fractures where the desorbed gas flows. The simulator also takes into account the use of gas adsorption isotherms recorded in the ECLIPSE 300 simulator by means of the extended Langmuir isotherm. In addition to the parameters of the extended Langmuir isotherm, the model also takes into account coal density, methane diffusion coefficient and minimum production pressure. ECLIPSE software defines the unit $\mathrm{sm}^{3} / \mathrm{kg}$ as a cubic meter of gas (at the pressure $1 \mathrm{~atm}=1013.25 \mathrm{hPa}$ and temperature $15.56{ }^{\circ} \mathrm{C}$ ) per kilogram of coal in situ [21].

The model of gas adsorption on coal for the different components is described in ECLIPSE 300 by means of The Extended Langmuir isotherm [23].The adsorption capacity is a function of the pressure and free gas phase composition. For each of the gases, it is required to introduce Langmuir isotherm parameters, i.e. the Langmuir volume constant $\mathrm{Vi}$ and the Langmuir pressure constant $\mathrm{Pi}$. These parameters are typical determined prom experiments. Different isotherms can be used in different regions of the field. The multicomponent adsorption capacity is calculated by the following equation (3):
$L\left(p, y_{1}, y_{2}, \ldots\right)_{\mathrm{i}}=\theta \frac{P_{s}}{R T_{s}}\left(V_{i} \frac{y_{i} \frac{p}{\bar{P}_{i}}}{1+\sum_{j=1}^{n c} y_{j} \frac{p}{p_{j}}}\right)$

where:

$\theta$ - scaling factor,

$P_{s}$ - pressure at standard conditions,

$R$ - universal gas constant,

Ts - temperature at standard conditions,

$V_{i}$ - Langmuir volume constant for component $i$,

$P_{i}$ - Langmuir pressure constant for component $i$,

yi - hydro carbon mole fraction in gas phase for component $i$,

$p$ - pressure.

For the special case of a single component, the Extended Langmuir isotherm is identical to the usual Langmuir isotherm giving the storage capacity as a function of pressure only (4):

$L(p)=\theta \frac{P_{s}}{R T_{s}}\left(V \frac{\frac{p}{P}}{1+\frac{p}{P}}\right)$

where $V$ is the maximum storage capacity for the gas, referred to as the Langmuir volume constant, and $\mathrm{P}$ is the Langmuir pressure constant. The constants used in the Extended Langmuir formulation can hence be estimated from a series of singlecomponent gas experiments.

It is possible to scale the adsorption capacity, keyword LANGMULT, by a factor for each cell in the grid. Typically this can be used to account for differences in ash or moisture contents.

Time dependent diffusion in ECLIPSE 300, i.e. the diffusive flow between the matrix and the fracture is given by the following equation (5):

$F_{i}=\operatorname{DIFFMF} \cdot D_{c, i} \cdot S_{g} \cdot R F_{i} \cdot\left(m_{i}-\rho_{c} L_{i}\right)$ where

$m_{i}-$ molar density in the matrix coal,

DIFFMF - matrix fracture (or multi porosity) diffusivity,

$\rho_{c}$ - rock density (coal density),

$D_{c, i}$ - diffusion coefficient (coal) component $i$,

$R F_{i}$ - readsorption factor component $i$,

$S_{g}$ - gas saturation, for desorption a value of unity is used,

$\rho_{c} L_{i}-$ equilibrium molar density of adsorbed gas.

The matrix-fracture diffusivity is given by (6): 
$D I F F M F=D I F F M M F \cdot V O L \cdot \sigma$ where DIFFMMF is the multiplying factor input, $V O L$ is the coal volume, $\sigma$ is the factor to account for the matrix-fracture interface area per unit volume.

Often the component's sorption time is a quantity that is easier to obtain than the diffusion coefficients. For desorption we write the flow as (7):

$F i=(V O L / \tau i)(m i-\rho c L i)$

where $\tau \mathbf{i}=1 /(\mathrm{Dc}, \mathbf{i} \cdot$ DIFFMMF $\cdot \sigma)$ is called the sorption time. The parameter controls the time lag before the released gas enters the coal fracture system. The sorption times are given by the diffusion coefficients, DIFFCBM, and the matrix-fracture interface area, SIGMA, together with the multiplying factor DIFFMMF. If the sorption times are known a value of unity can be assigned to $\sigma$ and DIFFMMF. The diffusion coefficients can then be assigned to the reciprocal of the sorption times [21].

\subsection{Location of the model}

The area selected for model tests is located in the south-western region of the Upper Silesian Coal Basin (USCB) in Poland, which is a prospective region for the needs of coal-bed methane (CBM) exploitation with the use of directional drilling technology. This area includes the WarszowicePawłowiceundeveloped hard coal deposit with methane as the main mineral.

The area of the Warszowice-Pawłowice Północ coal deposit was selected for the task implementation (Fig. 1) due to its high methane content.

\subsection{Method of estimating methane resources in the Warszowice-Pawłowice Pótnoc deposit}

In Poland, 65 methane deposits have been documented, the total balance of resourcesis 109.5 billion $\mathrm{m}^{3}$ [25]. The evaluation of the current methane conditions of the Warszowice-Pawłowice Północ deposit was determined on the basis of the results of tests carried out in the boreholes drilled for exploration of the deposit in the category $\mathrm{C} 1+\mathrm{C} 2$. All methods for coal deposits known at that time and available for use were used in the research. For the assessment, 540 results of methane content measurements, 259 results of desorbometric measurements, and 43 sandstone layers were analysed [26].

Methane in the Upper Carboniferous rock mass is genetically bound to coal. It is formed by thermocatalytic process as a result of carbonization of humic substance. In hard coal deposits it occurs in

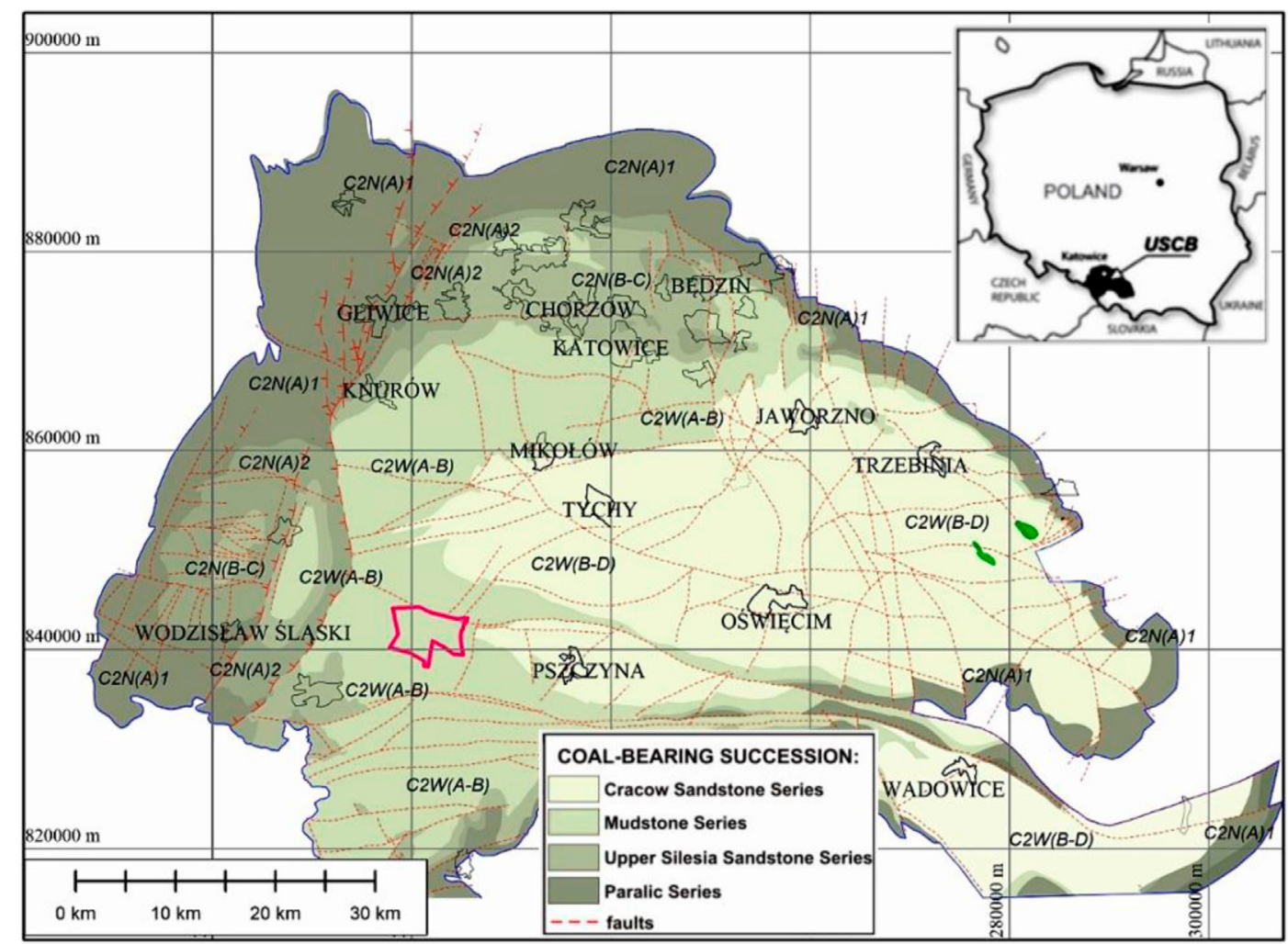

Fig. 1. Location of the Warszowice-PawłowicePótnoc deposit area ([24], changed). 


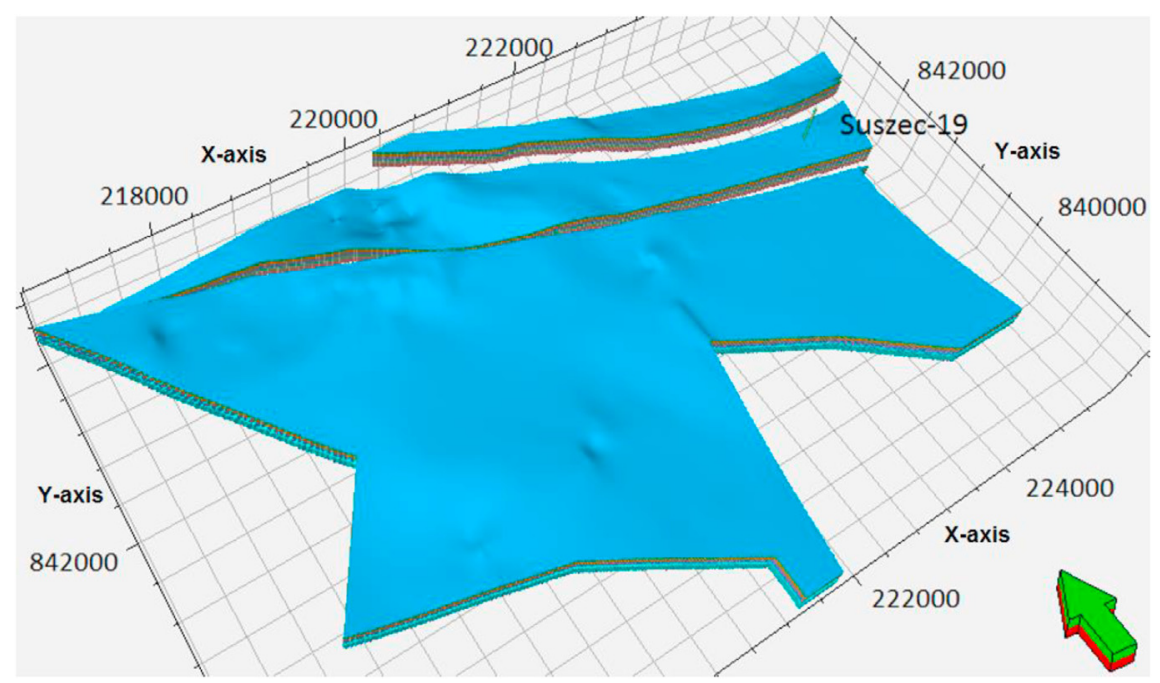

Fig. 2. Structural model of hard coal seams; the position of the arrow points to the north.

two forms, as: sorbed methane i.e., physically and chemically bound to the carbon substance of coal seams and dispersed in waste rocks, or free methane filling pores and fractures in coal seams, porous waste rocks, fault zones etc.

Within the boundaries of the deposit, the methane content of coal seams ranges from $0.018 \mathrm{~m}^{3} / \mathrm{Mg}_{\text {daf }}$ (dry and ash-free) to $17.756 \mathrm{~m}^{3} / \mathrm{Mg}_{\text {daf }}$. Estimated methane balance resources amounted to 3.82 billion $\mathrm{m}^{3}$.

Methane resources have been estimated with the use of the given hydrocarbon content of coal seams determined by the vacuum degasification method. The calculations do not include methane contained in pores, the coal fracture system and waste rock as well as methane sorbed in coal substance dispersed in the rock mass.

The resources were calculated using formula (8):

$$
\mathrm{Qm}=\mathrm{Qw} \mathrm{w}_{1} \mathrm{w}_{2}\left(\mathrm{G}_{\mathrm{S} R}-\mathrm{G}_{\mathrm{R}}\right) \cdot \mathrm{W}_{\mathrm{T}}\left[\mathrm{Nm}^{3}\right]
$$
where:

$Q_{m}$ - methane resources in thousands cubic meters $\left(\mathrm{m}^{3}\right)$,

Table 1. Structural parameters of the simulation model.

\begin{tabular}{lll}
\hline Parameter & Value & Unit \\
\hline $\begin{array}{l}\text { Area of the model } \\
\begin{array}{l}\text { Horizontal resolution of the } \\
\text { interpolation grid }\end{array}\end{array}$ & 211700 & $\mathrm{~m}^{2}$ \\
$\begin{array}{l}\text { Fracture porosity } \\
\text { Coal permeability }\end{array}$ & $10 \times 10$ & $\mathrm{~m}$ \\
Temperature & 2 & $\%$ \\
Density of coal & 33 & $\mathrm{mD}$ \\
Total moisture content & 1330 & ${ }^{\circ} \mathrm{C}$ \\
Ash content & 3.19 & $\mathrm{~kg} / \mathrm{m}^{3}$ \\
\hline
\end{tabular}

$Q_{w}-$ documented coal resources in thousand tons $(\mathrm{Mg})$

$w_{1}$ - coefficient increasing coal reserves with undocumented coal seams and coalinserts,

$w_{2}$ - conversion coefficient of total geological coal resources into total geological resources of dry and ash-freecoal substance (daf),

$G_{S ́}$ - average arithmetic mean methane content in $\mathrm{m}^{3} \mathrm{CH}_{4} / \mathrm{Mg}_{\text {daf }}$ in the calculation interval,

$\mathrm{G}_{R}$ - residual methane content in $\mathrm{m}^{3} \mathrm{CH}_{4} / \mathrm{Mg}_{\text {daf }}$, determined by vacuum degasification,

$W_{\mathrm{T}}$ - temperature coefficient $(0.9017)$ determining gas resources under normal conditions $\left(0{ }^{\circ} \mathrm{C}\right.$, $760 \mathrm{~mm} \mathrm{Hg}$ ).

\section{Results and discussion}

3.1. Construction of a numerical model to produce methane from coal seams

The Warszowice-Pawłowice Północ hard coal deposit area has been selected as a potential

Table 2. Parameters used for modelling of methane extraction from coal.

\begin{tabular}{lll}
\hline Parameter & Value & Unit \\
\hline Initial pressure & $40-60$ & bar \\
$\begin{array}{l}\text { Minimumproduction pressure } \\
\text { CH4 Diffusion coefficient, }\end{array}$ & 5 & bar \\
$\begin{array}{l}\text { Extended Langmuir isotherm } \\
\text { parameters }\end{array}$ & 0.0000685 & $\mathrm{~m}^{2} / \mathrm{d}$ \\
$\mathrm{CH}_{4}$ volume $\mathrm{V}_{\mathrm{L}}$ & & \\
$\mathrm{CH}_{4}$ pressure $\mathrm{P}_{\mathrm{L}}$ & 0.0205 & \\
$\mathrm{CO}_{2}$ volume $\mathrm{V}_{\mathrm{L}}$ & 42.00 & $\mathrm{sm}^{3} / \mathrm{kg}$ \\
$\mathrm{CO}_{2}$ pressure $\mathrm{P}_{\mathrm{L}}$ & 0.0320 & $\mathrm{bar}^{3}$ \\
\hline & 19.03 & $\mathrm{sm}^{3} / \mathrm{kg}$ \\
& & $\mathrm{bar}$ \\
\hline
\end{tabular}


Table 3. Parameters of coal seams in the selected area.

\begin{tabular}{llll}
\hline Coal seam & Depth of deposition, $\mathrm{m}$ & Thickness, $\mathrm{m}$ & Average methane content, $\mathrm{m}^{3} / \mathrm{Mg}_{\text {daf }}$ \\
\hline $338 / 1$ & $\sim 400$ & 2.00 & 7.368 \\
$340 / 2$ & $\sim 500$ & 1.70 & 10.163 \\
$345 / 1$ & $\sim 600$ & 2.00 & 8.121 \\
\hline
\end{tabular}

Table 4. Methane resources.

\begin{tabular}{lllll}
\hline Seam & $\begin{array}{l}\text { Thickness, } \\
\mathrm{m}\end{array}$ & $\begin{array}{l}\text { Cell volume, } \\
\mathrm{m}^{3}\end{array}$ & Mean methane content, $\mathrm{m}^{3} / \mathrm{Mg}_{\text {daf }}$ & Methane resources, $\mathrm{m}^{3}$ \\
\hline $338 / 1$ & 2.00 & 3164800 & 7.368 & 23259950.8 \\
$340 / 2$ & 1.70 & 2690080 & 10.163 & 27270934.8 \\
$345 / 1$ & 2.00 & 3164800 & 8.121 & 25637087.5 \\
\hline
\end{tabular}

prospective area for coal bed methane exploitation using directional boreholes drilled from the surface.

For the construction of a static model of coal seam, Petrel software 2010.1 was used, while the methane drainage process was simulated using a composition version of the ECLIPSE simulator with the Coal Bed Methane option, which takes into account the processes of coal seam methane production.

Figure 2 shows a structural model that was created using data from maps of coal seams (such as isolines of the top surface of Carboniferous deposit, isopachous line, faults, borehole data). The developed model shows the deposit of selected coal seams including the following coal seams: 336/1, 338/1, 339, $340 / 1,340 / 2,345 / 1$. The area of the modelled area is $37.27 \mathrm{~km}^{2}$.

For the simulation in subsequent stages, a smaller area of about $2 \mathrm{~km}^{2}$, limited to the north and south by regional faults Jawiszowicki II and III was selected. The horizontal resolution of the interpolation grid of $10 \times 10 \mathrm{~m}$ was applied. Static numerical model consists of 3 coal and 188271 cells. Detailed parameters of model are compiled in Table 1.

Laboratory data obtained during the execution of RECOPOL project $[27,28]$ were used in the developed model.Detailed parameters of simulation model are compiled in Table 2.

\subsection{Estimation of coalbedmethaneresourcesusing model tests}

The current state of recognition of methane conditions of the Warszowice-PawłowicePółnoc deposit is based solely on the results of tests carried out in the boreholes drilled for exploration of the deposit in the $C_{1}+C_{2}$ category. All methods for coal deposits known at that time and available for use were used in the research. In total, about 540 results of methane content measurements, 259 results of desorbometric measurements were compared and used. Average methane content, depth and

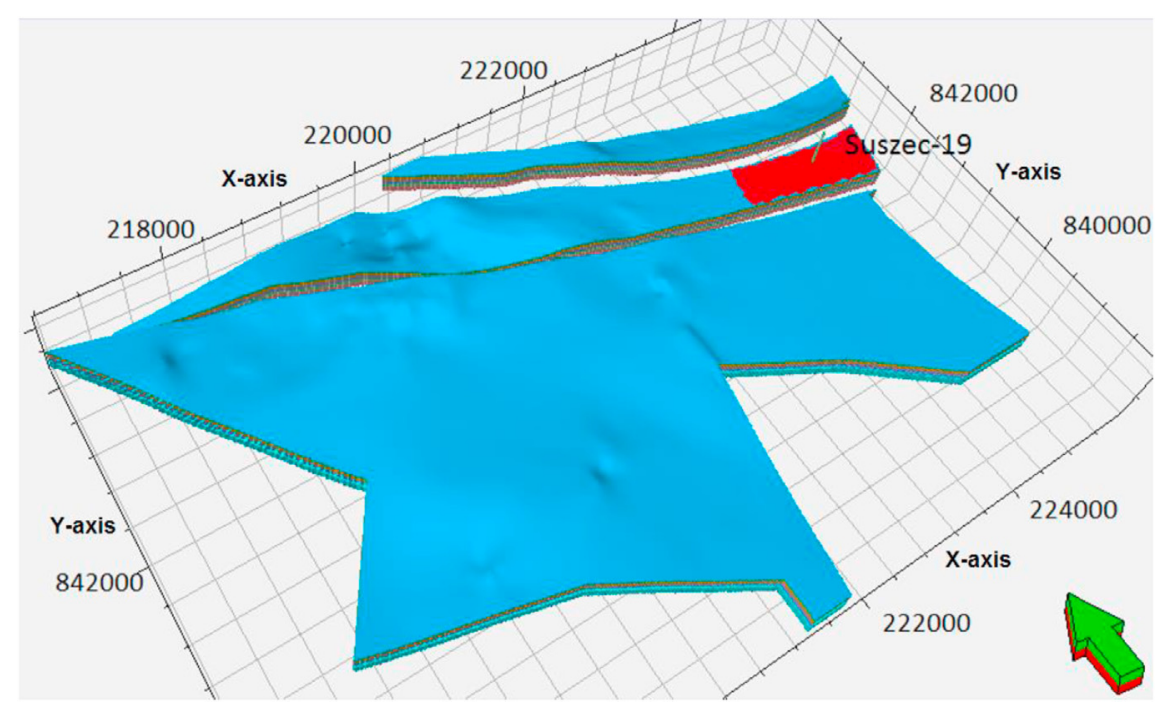

Fig. 3. Structural model of hard coal seams with selected part of the model to simulate methane exploitation process; the position of the arrow points to the north. 


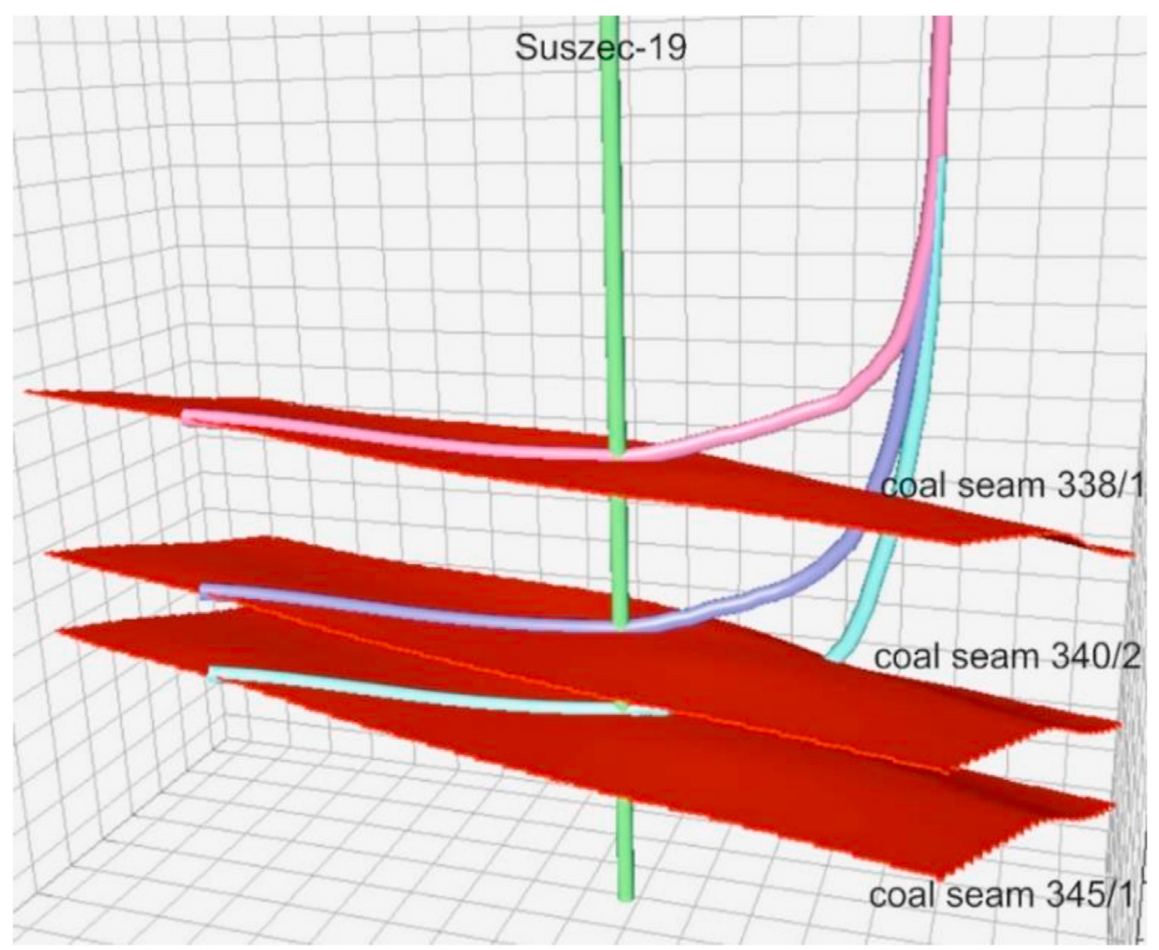

Fig. 4. Selected part of the model to simulate methane exploitation process.

thickness of selected coal seams in the analysed area are presented in Table 3.

Methane resources in total amounted to about 77 million $\mathrm{m}^{3}$ of methane were calculated on the basis of the model for the following coal seams: 338/1, $340 / 2$ and 345/1. Table 4 presents the coal bed methane resources for individual coal seams.
3.3. Computer simulations of methane production with boreholes from the surface using eclipse software by Schlumberger

The aim of the simulations was to compare the production of methane for the assumed six variants including gas intake from one, two and three seams for assumed two types of boreholes: directional

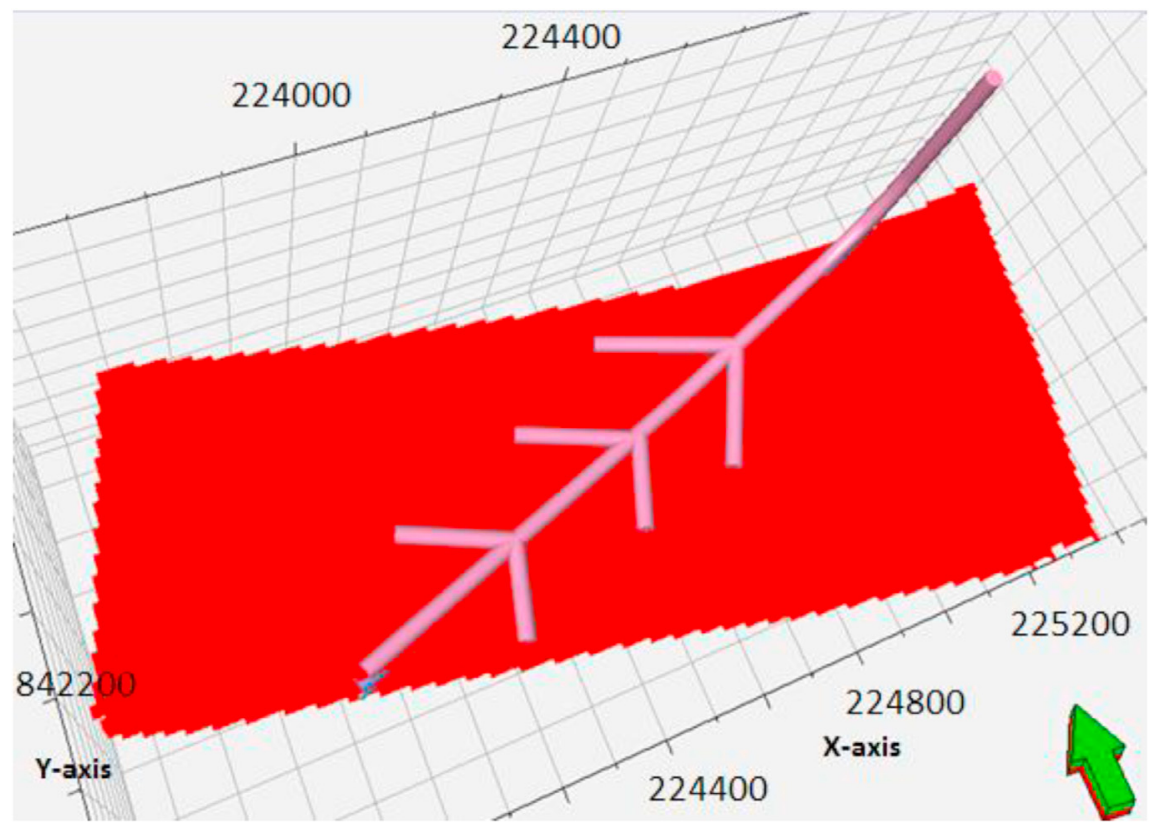

Fig. 5. Arrangement scheme of z-pinnate boreholes on seam 338/1; the position of the arrow points to the north. 


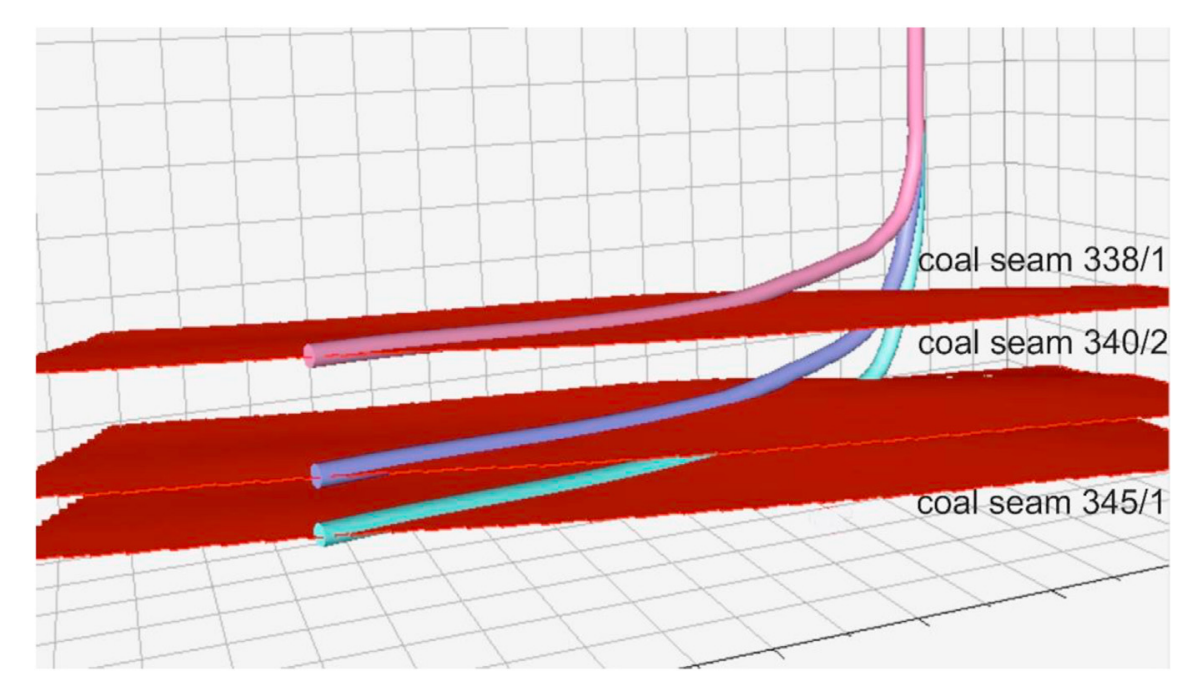

Fig. 6. Arrangement scheme of directional boreholes.

Table 5. Cumulative methane production.

\begin{tabular}{llllll}
\hline Variant & $\begin{array}{l}\text { Number of active } \\
\text { directional boreholes }\end{array}$ & Z-pinnate method & $\begin{array}{l}\text { Methane } \\
\text { production, } \mathrm{m}^{3}\end{array}$ & $\begin{array}{l}\text { Methane } \\
\text { drainage, } \mathrm{m}^{3}\end{array}$ & $\begin{array}{l}\text { Degree of methane } \\
\text { production, } \%\end{array}$ \\
\hline 1 & 1 & No & 3312611 & 23259950.8 & 14.2 \\
2 & 2 & No & 10252754 & 50530885.6 & 19.3 \\
3 & 3 & No & 14877435 & 76167973.1 & 19.5 \\
4 & 1 & Yes & 3877530 & 23259950.8 & 16.7 \\
5 & 2 & Yes & 11994710 & 50530885.6 & 21.7 \\
6 & 3 & Yes & 16697180 & 76167973.1 & 21.9 \\
\hline
\end{tabular}

wells and system of horizontal boreholes in a multiwell pattern using z-pinnate method.

Analyses were carried out for directional boreholes drilled from surfaces connected to the existing Suszec-19 borehole (Figs. 3 and 4), as well as for those boreholes together with a grid of z-pinnate boreholes of $200 \mathrm{~m}$ in length, drilled at an angle of 45 (Figs. 5 and 6). The amount of methane production was investigated, depending on the number of active boreholes within the period of 10 years.Horizontal wells were designed on the basis of the lithological description of the existing Suszec-19 borehole. Coal layers are divided by clay layers, which is the natural permeability limit.

A number of simulations related to methane production from the selected deposits were performed. They included different variants of the number of boreholes and also took into account the z-pinnate method.

In variant 1 , methane was produced from coal seam 338/1 with one directional borehole, its production was 3.3 million $\mathrm{m}^{3}$, which constitutes $14.2 \%$ of the resources of the analysed fragment of the deposit.

In variant 2 , methane was produced from deposits $338 / 1$ and $340 / 1$ by two directional boreholes, its production was 10.2 million $\mathrm{m}^{3}$, which constitutes $19.3 \%$ of the resources of the analysed fragment of the deposit.

In variant 3 methane was produced from three deposits 338/1, 340/1 and 345/2 with three directional holes, its production was 14.9 million $\mathrm{m}^{3}$, which constitutes $19.5 \%$ of the resources of the analysed fragment of the deposit.

In variant 4 , in which the z-pinnate method was used to produce 1 borehole, the forecast output increased to 3.8 million $\mathrm{m}^{3}$, which represents $16.7 \%$ of the methane resources.

In variant 5 , in which the z-pinnate method was used in the production of two boreholes, the forecast output increased to 12 million $\mathrm{m}^{3}$, which is $21.7 \%$ of the methane resources.

In variant 6 , in which the z-pinnate method was used for the production of three boreholes, the forecast output increased to 16.7 million $\mathrm{m}^{3}$, which constitutes $21.9 \%$ of the methane resources. Table 5 shows the cumulative methane production from coal seams in different variants of numerical simulation.

Figures 7 and 8 show the comparison of methane production from coal seams during the different variants of simulation. The results of numerical 


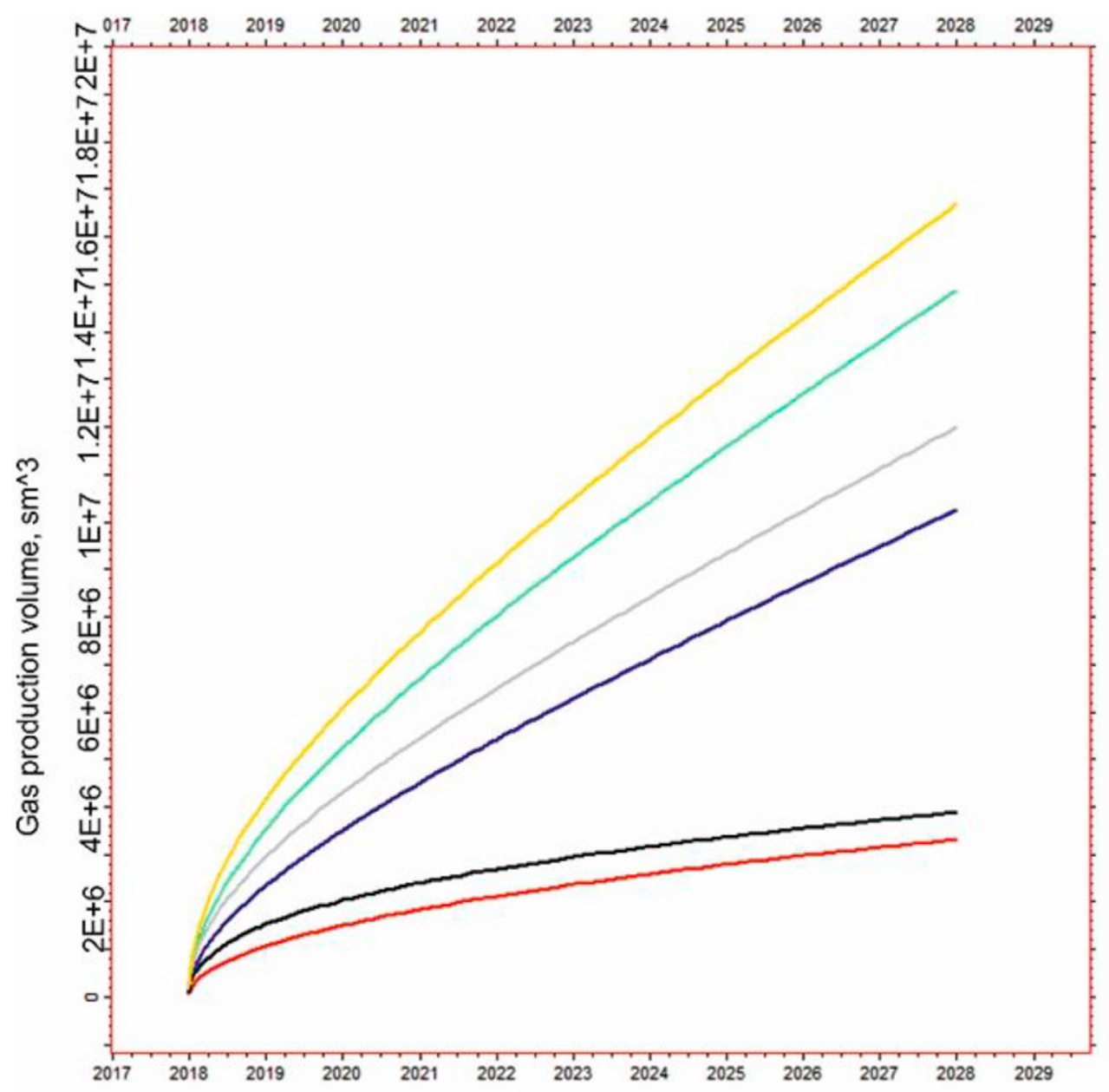

wariant $1-$ wariant $2-$ wariant $3-$ wariant $4-$ wariant $5-$ wariant 6

Fig. 7. Methane extraction from coal seams during the different variants of simulation.

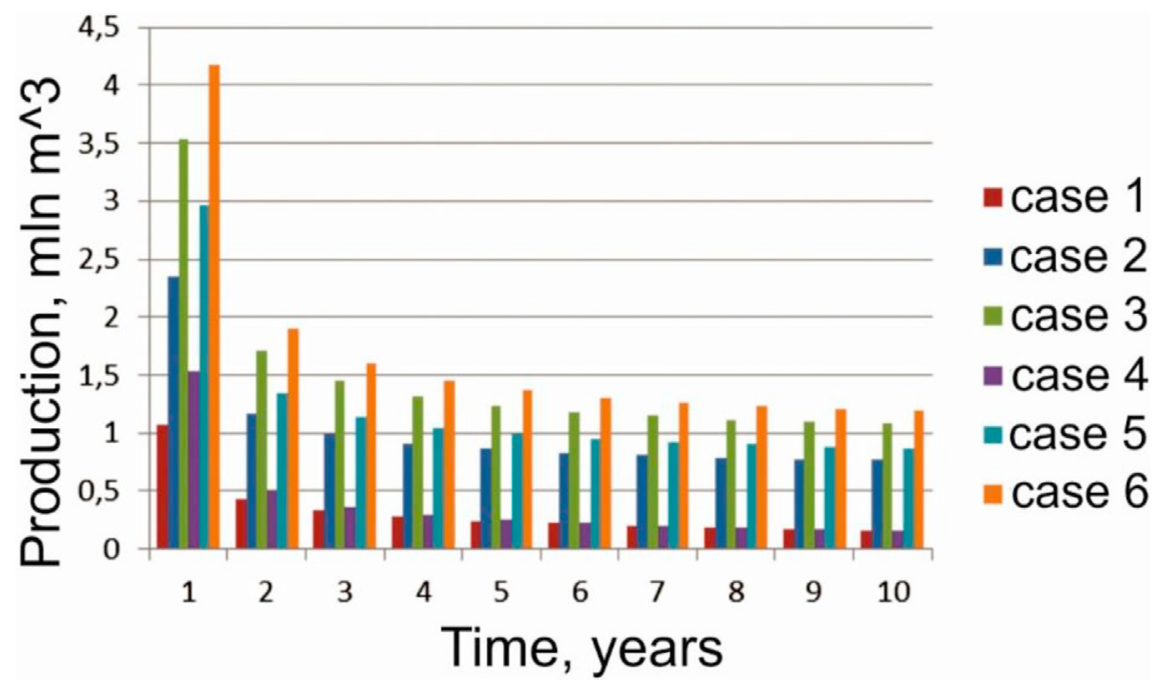

Fig. 8. Methane extraction from coal seams in subsequent years of the different variants of simulation. 


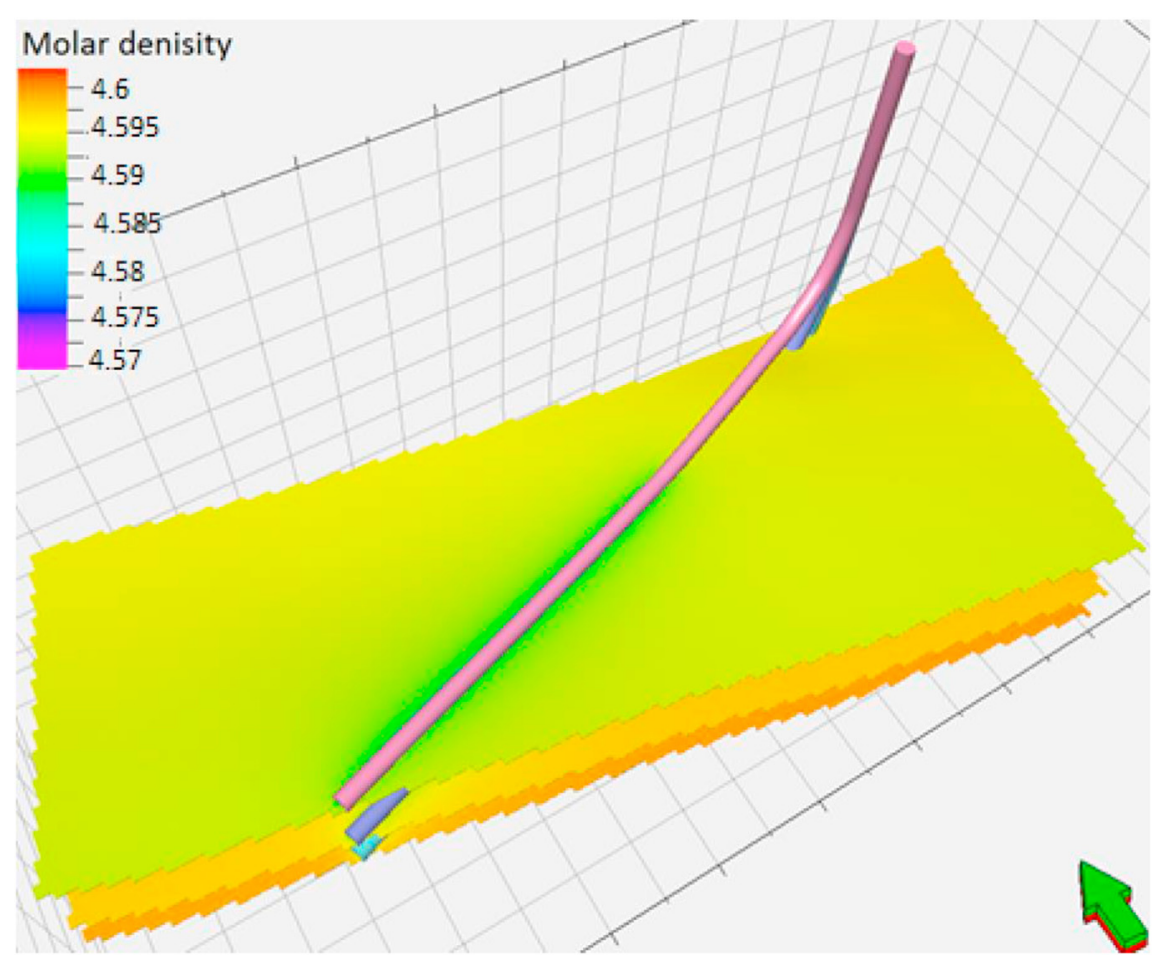

Fig. 9. Molar density of methane in coal matrix for variant 3; the position of the arrow points to the north.

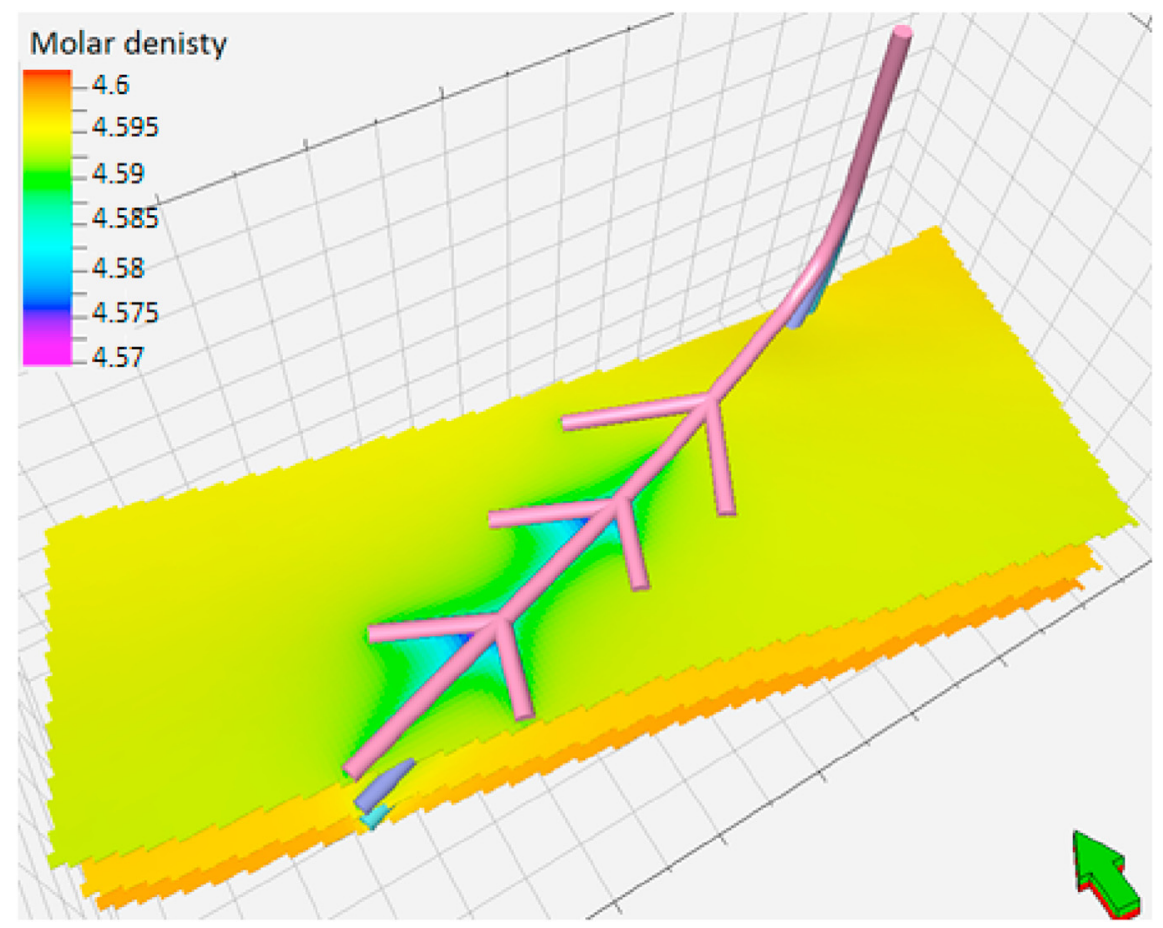

Fig. 10. Molar density of methane in coal matrix for variant 6; the position of the arrow points to the north. 


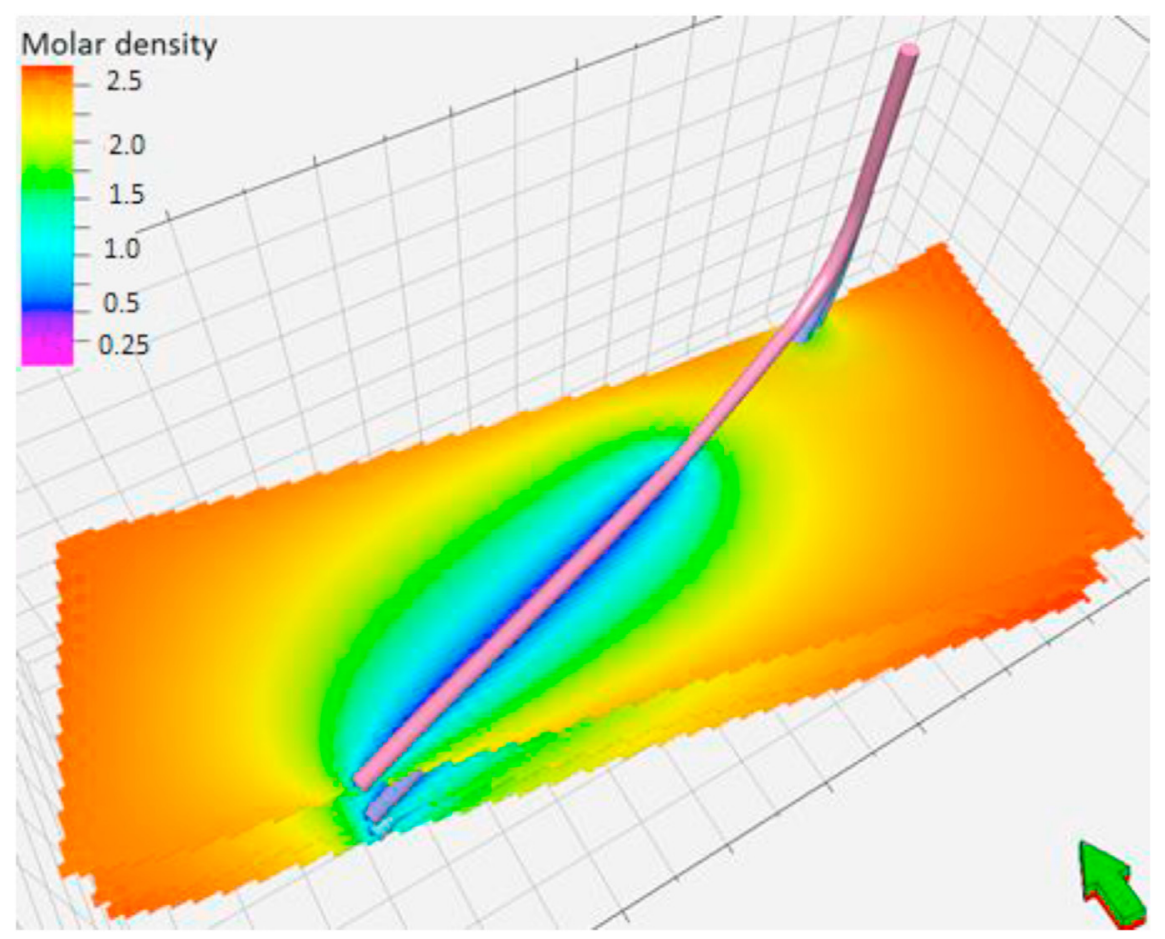

Fig. 11. Molar density of methane in coal fractures for variant 3; the position of the arrow points to the north.

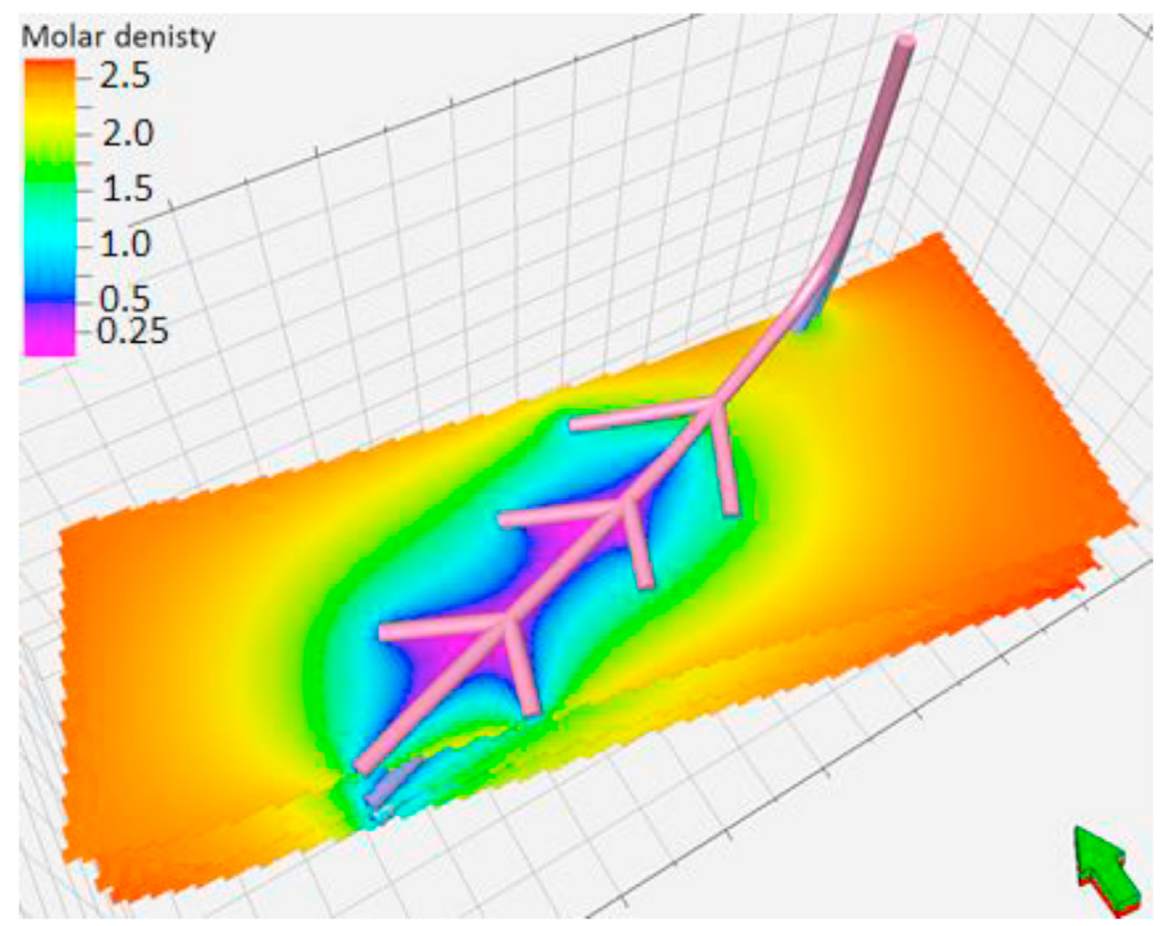

Fig. 12. Molar density of methane in coal fractures for variant 6; the position of the arrow points to the north. 


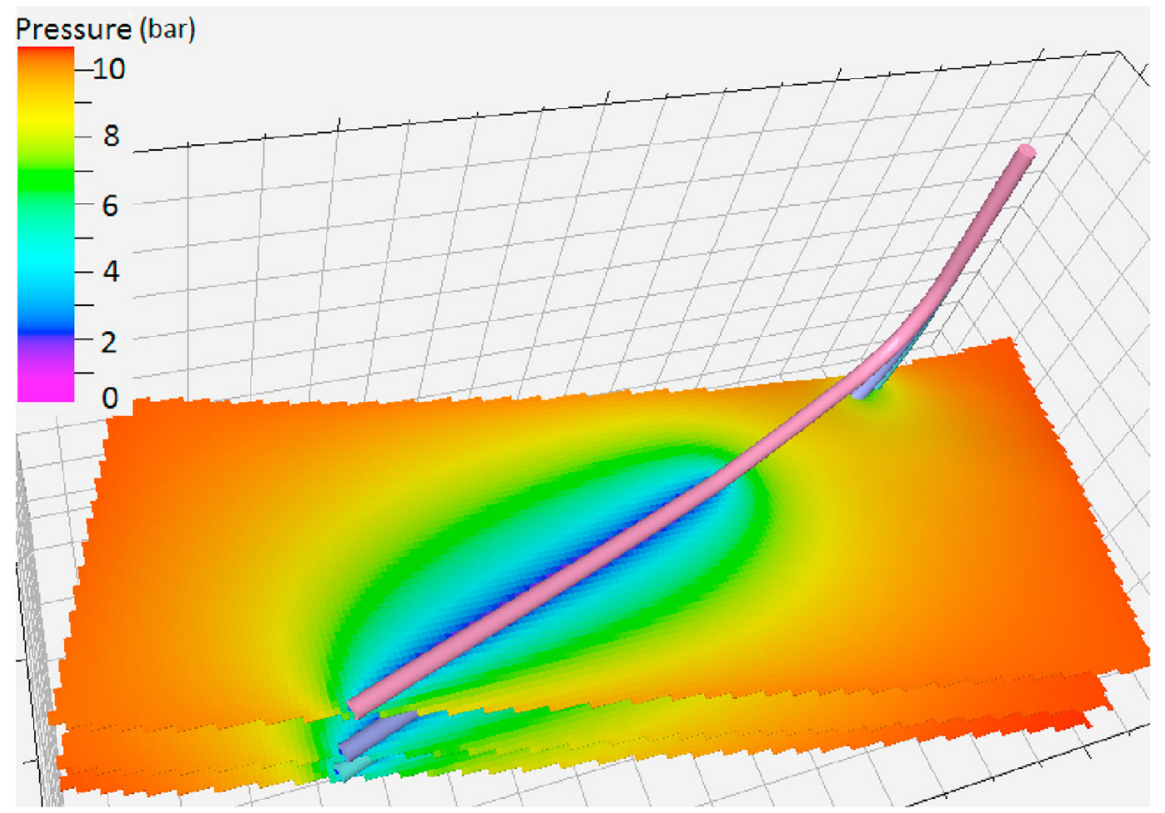

Fig. 13. Pressure distribution for variant 3.

simulation indicate that in all considered variants, the highest output of methane was in the first year of the process.

Figures 9 and 10 presents the changes in the distribution of molar density of methane in coal matrix at the end of numerical simulation within the framework of variant 3 and 6.
Figures 11 and 12 presents the changes in the distribution of molar density of methane in coal fractures at the end of numerical simulation within the framework of variant 3 and 6 .

Figures 13 and 14 presents the changes in the distribution of coal seam pressure during the simulation of methane extraction. Observed decrease in the rock mass pressure was caused by

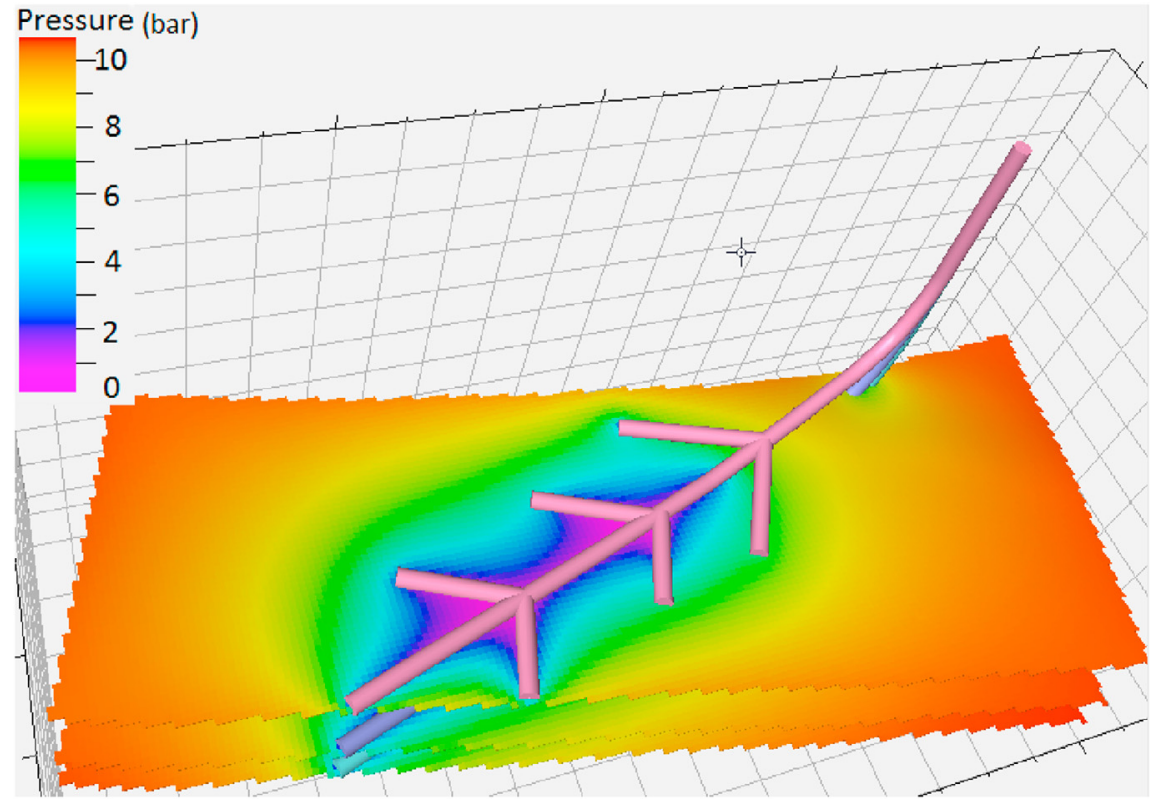

Fig. 14. Pressure distribution for variant no. 6 . 
the extraction of water and methane from the coal seams. The simulation variants show that the pressure variation zones the pressure distribution in the zone of directional borehole that is up to approx. 400 m.

\section{Conclusions}

The paper uses Eclipse software to simulate the process of methane drainage and efficiency assessment of this process depending on the initial conditions in the analysed seam as well as the selection of drainage borehole parameters.

The research carried out to simulate methane production with the use of various borehole systems from the surface allowed to indicate the system of horizontal boreholes in a multi-well pattern using zpinnate method with lengths of $200 \mathrm{~m}$ drilled at an angle of 45 as the most advantageous borehole system to methane extraction from coal seams.

The application of the z-pinnate method is connected with obtaining greater extraction than in using of the directional borehole only, however, it should be combined with the economic analysis.The highest degree of methane production $(21.9 \%)$ was achieved for variant no. 6 , in which the z-pinnate method of directional boreholes was used and all boreholes were active for 10 years.

Test results obtained within the framework of numerical simulation in variant no. 6 can be used for further simulation studies of methane extraction for the entire Warszowice-PawłowicePółnoc deposit and analyses of methane extraction using several production boreholes in order to estimate the cost of the process using the Monte Carlo method and thus determine profits and losses assuming methane production from the entire deposit.

\section{Ethical statement}

The authors state that the research was conducted according to ethical standards.

\section{Funding body}

The research was conducted within the framework of the statutory works of the Central Mining Institute (Główny Instytut Górnictwa) and financed by the Ministry of Science and Higher Education (work number:14102017-122).

\section{Conflicts of interest}

None declared.

\section{References}

[1] Słoczyński T, Drozd A. Metan z pokładów węgla (CBM) doświadczenia światowe i perspektywy rozwoju w Polsce. 2017.

[2] Gonet A, Nagy S, Rybicki C, Siemek J, Stryczek S, Wiśniowski R. Technologia wydobycia metanu z pokładów węgla (CBM). Górnictwo i Geologia; 2010.

[3] Chećko J, Urych T, Magdziarczyk M, Smoliński A. Resource assessment and numerical modeling of CBM extraction in the upper Silesian Coal Basin, Poland. Energies 2020;13(9): 2153. https://doi.org/10.3390/en13092153.

[4] Hadro J, Wójcik I. Metan pokładów węgla: zasoby i eksploatacja. Przeglad Geol 2013;61(7):408.

[5] Tao Shu, Pan Zhejun, Tang Shuling. Shida Chen Current status and geological conditions for the applicability of CBM drilling technologies in China. Int J Coal Geol 2019;202: 95-108.

[6] Yao Yanbin\& Liu, Tang Dameng, Tang Dazhen, Shuheng\&Che Yao, Huang Wenhui. Preliminary evaluation of the coalbed methane production potential and its geological controls in the Weibei Coalfield, Southeastern Ordos Basin, China. Int J Coal Geol 2009;78:1-15. https:// doi.org/10.1016/j.coal.2008.09.011.

[7] Wojtacha-Rychter K, Howaniec N, Smoliński A. The effect of coal grain size on the sorption of hydrocarbons from gas mixtures. Int J Energy Res 2019;43:3496-506.

[8] Ceglarska-Stefańska G, Nodeński A, Hołda S. Badania układu węgiel-gaz $\mathrm{w}$ aspekcie pozyskania metanui sekwestracji CO2. Gos Sur Min 2007;23:51-9.

[9] Wojtacha-Rychter K, Smoliński A. The interactions between coal and multi-component gas mixtures in the process of coal self-heating at diferent various temperatures ranges: an experimental study. Fuel 2018;213:150-7.

[10] Aminian K. Evaluation of coalbed methane reservoirs. Petroleum \& Natural Gas Engineering Department, West Virginia University; 2009.

[11] Mazzotti M, Pini R, Storti G. Enhanced coalbed methane recovery. J Supercrit Fluids 2009;47(3):619-27.

[12] Liu Y, Wang F, Tang H, Liang S. Well type and pattern optimization method based on fine numerical simulation in coal-bed methane reservoir. Environ Earth Sci 2015;73(10): 5877-90.

[13] Zhang M, Yang Y, Xia Z, Cui Z, Ren B, Zhang W, et al. Best practices in static modelling of a coalbed methane field: an example from the bowen basin in Australia. Society of Petroleum Engineers; 2014. https://doi.org/10.2118/171416-MS.

[14] Zhou F, Yao G, Tyson S. Impact of geological modeling processes on spatial coal bed methane resource estimation. Int J Coal Geol 2015;146(146):14-27.

[15] Shi JQ, Durcan S, Sinka IC. Key parameters controlling coalbed methane cavity well performance. Int J Coal Geol 2002;49:19-31.

[16] Sinayuc C, Shi JQ, Imrie CE, Syed SA, Korre A, Durucan S. Implementation of horizontal well CBM/ECBM technology and the assessment of effective $\mathrm{CO} 2$ storage capacity in a Scottish coalfield. Energy Proc 2011;4:2150-6.

[17] Galas C, Savenko V, Kieke DE. Simulation study of methane and carbon dioxide migration and Leakage during normal and enhanced field operations to recover coal bed methane from coal seams. In: Eide LI, editor. Carbon dioxide capture for storage in deep geologic formations, vol. 3. UK: CPL Press; 2009. 2009.

[18] Anggara F, Sasaki K, Amijaya H, Sugai $\mathrm{Y}$, Setijadji LD. $\mathrm{CO}_{2}$ injection in coal seams, an option for geological $\mathrm{CO}_{2}$ storage and enhanced coal bed methane recovery (ECBM). In: Proceedings, Indonesian petroleum association. Thirty-Fourth Annual Convention \& Exhibition; May 2010.

[19] Jureczka J, Chećko J, Krieger W, Kwarciński J, Urych T. Prospects for geological storage of $\mathrm{CO} 2$ with enhanced coal 
bed methane recovery in the Upper Silesian Coal Basin. Biul Panstwowego Inst Geol (1989) 2012;448:117-31.

[20] Chećko J, Urych T, Magdziarczyk M, Smoliński A. Research on the processes of injecting $\mathrm{CO}_{2}$ into coal seams with $\mathrm{CH}_{4}$ recovery using horizontal wells. Energies 2020;(13):416.

[21] ECLIPSE reservoir engineering software. 2011. Schlumberger, version 2011.3.

[22] Petrel seismic-to-simulation software. Schlumberger; 2010. version 2010.1

[23] Arri LE, Yee D, Morgan WD, Jeansonne NW. Modeling coalbed methane production with binary gas sorption. 1992. SPE 24363.

[24] Buła Z, Kotas A. (red.). Atlas geologiczny Górnośląskiego Zagłębia Węglowego Cz. III - mapy geologiczno-strukturalne, 1:100 000. Warszawa: Państw. Inst. Geol.; 1994.
[25] Szuflicki M, Malon A, Tymiński M. (red.): bilans zasobów złóż kopalin w Polsce wg stanu na 31.12.2019 r. Praca zbiorowa PSG PIG - PIB. Warszawa: PGI-NRI; 2020. wydawca PIG - PIB, ISSN: 2299-4459. Proven reserves of mineable deposits in Poland as of 31 Dec 2019.

[26] Jędrzejewski J. Dodatek nr 5 do dokumentacji geologicznej złoża węgla kamiennego Warszowice-Pawłowice Północ w kat. B, C1, C2. 2011.

[27] Reeves S, Taillefert A. Reservoir modeling for the design of the RECOPOL $\mathrm{CO}_{2}$ sequestration project, Poland-topical report. Advanced Resources International; 2002.

[28] Wageningen WFC, Maas JG. Reservoir simulation and interpretation of the RECOPOL ECBM pilot in Poland, Int. CBM. Symposium: Tuscaloosa AL; 2007. 